\title{
Assessing hydrothermal treatment and antagonistic yeasts combination for mango anthracnose control
}

\author{
Evaluación de la combinación del tratamiento hidrotérmico y levaduras antagonistas para el control \\ de la antracnosis en mango
}
María de Jesús Ochoa-Rosas (D) , Ernestina Valadez-Moctezuma² (D) , Gustavo Mena-Nevarez² (D), Teodoro Espinosa-Solares ${ }^{1}$ (iD) , Artemio Pérez-López ${ }^{1 *}$ (i)

1Departamento de Ingeniería Agroindustrial, Universidad Autónoma Chapingo (UACh), Carr. México-Texcoco km 38.5, Chapingo, 56230, Texcoco de Mora, México, México.

${ }^{2}$ Departamento de Fitotecnia (UACh).

${ }^{*}$ Corresponding author: aperezl.dia@gmail.com

Received:

June $4^{\text {th }}, 2020$

Acceptance date:

February $14^{\text {th }}, 2021$

Online publication date: June 19th, 2021

Este es un artículo en acceso abierto que se distribuye de acuerdo a los términos de la licencia Creative Commons.

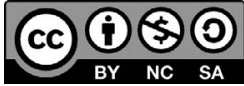

Reconocimiento-

NoComercia-

CompartirIgual 4.0

Internacional

\section{ABSTRACT}

Anthracnose caused by Colletotrichum species is the main post-harvest disease in mango in almost all production areas in the world. Hydrothermal treatment (HT) and antagonism of yeasts Pichia guilliermondii Wick., Candida oleophila Montrocher, and C. quercitrusa S. A. Mey. \& Phaff were evaluated in vitro and in vivo in order to determine its effectiveness on anthracnose in 'Ataulfo' mango. The pathogen and the yeasts were prepared at concentrations of $10^{5}$ conidia $\bullet \mathrm{mL}^{-1}$ and $10^{8}$ cells $\mathrm{mL}^{-1}$, respectively. The most effective strains in in vitro assays and HT were evaluated in 'Ataulfo' mango inoculated with Colletotrichum spp. In in vitro assays, P. guilliermondii strain CDBB-932 was most effective in controlling the mycelial growth of the pathogen, whereas in in vivo assays, the combination HT with C. quercitrusa (strain 42) showed the greatest effectiveness. Hydrothermal treatment in combination with yeasts could be implemented as preventive control of anthracnose in mango postharvest.

\section{KEYWORDS}

Colletotrichum spp.; microbial antagonists; biological control agents; 'Ataulfo' mango; heat treatment.

\section{RESUMEN}

La antracnosis, causada por especies de Colletotrichum, es la enfermedad postcosecha más importante en el mango a nivel mundial. Se evaluaron el tratamiento hidrotérmico (HT) y el antagonismo de levaduras de Pichia guilliermondii Wick., Candida oleophila Montrocher y C. quercitrusa S. A. Mey. \& Phaff, in vitro e in vivo, para determinar su efectividad sobre antracnosis en mango 'Ataulfo'. El patógeno y las levaduras se prepararon en concentraciones de $10^{5} \operatorname{conidios}^{\bullet} \mathrm{mL}^{-1} \mathrm{y}$ $10^{8}$ células $\bullet \mathrm{mL}^{-1}$, respectivamente. Las cepas con mayor efectividad en los ensayos in vitro y el HT se evaluaron en mango 'Ataulfo' inoculado con Colletotrichum spp. En ensayos in vitro, la cepa CDBB-932 de P. guilliermondii tuvo mayor inhibición del crecimiento micelial del patógeno, y en ensayos in vivo, la combinación HT con C. quercitrusa (cepa 42) mostró mayor eficacia. El tratamiento hidrotérmico en combinación con levaduras podrían implementarse como control preventivo de antracnosis en mango. 
PALABRAS CLAVE

Colletotrichum spp.; antagonistas microbianos; agentes de control biológico; mango 'Ataulfo'; tratamiento con calor.

\section{INTRODUCTION}

The mango (Mangifera indica L.) is an important crop for the international market due to its flavor, aroma, color, and nutritional properties (Evans et al. 2017). It has been reported that 'Ataulfo' mango has a higher level of $\beta$-carotene, ascorbic acid, total phenols, and antioxidant activity than other commercial varieties such as Haden, Kent, Keitt, and Tommy Atkins (Kabir et al. 2017; Mercado-Mercado et al. 2018). Mango fruit has high moisture content and a nutrient-rich profile, making it highly susceptible to different pathogens, including fungi and bacteria. Anthracnose, caused mainly by Colletotrichum species (De Souza-Pollo and De Goes 2017; Wu et al. 2020), is the primary postharvest disease in mango; it is considered a critical point that destabilizes the fruit value chain in almost all production areas (Konsue et al. 2020). It has been reported that 87 Colletotrichum species are associated with anthracnose symptoms in mangoes (Wu et al. 2020). Fungicides, either as pre or postharvest control methods, have been mainly used to reduce the loss caused by anthracnose. However, the use of chemicals is increasingly restricted due to the induction of resistance in the pathogens and public concern over the toxic residues that are harmful to the environment and public health, which has generated the search for other control options (Gómez-Maldonado et al. 2020; Vilaplana et al. 2020).

Hydrothermal treatment (HT) is a safe and non-chemical method that has been used to control postharvest disease in some fruit species (Usall et al. 2016). It has been proposed that HT, alone or with chemical products, can also control anthracnose in mango in postharvest. In Mexico, HT is an established practice as a condition for exporting mango to the United States, Japan, Chile, New Zealand, and Australia (Luna et al. 2006; Brecht and Yahia 2017). The quality of 'Ataulfo' mango subjected to HT (46.1 ${ }^{\circ} \mathrm{C}$ for $75 \mathrm{~min}$ ) has been evaluated (Luna et al. 2006). According to the study, HT accelerated the ripening process, fruits developed better color and less titratable acidity, and the sensory characteristics did not vary significantly under preservation at temperatures above $13{ }^{\circ} \mathrm{C}$ during two weeks.

In recent years, the search for alternatives for anthracnose control has increased, and biological control has become essential for successful postharvest application (Dukare et al. 2019). Previous research has reported the use of bacteria and yeast such as Stenotrophomonas rhizophila Wolf et al. (Hernández-Montiel et al. 2017; Reyes-Pérez et al. 2019), Burkholderia cepacia (Palleroni and Holmes) Yabuuchi et al. (De los Santos-Villalobos et al. 2012), Debaryomyces hansenii (Zopf) Lodder \& Kreger-van Rij, Meyerozyma caribbica (Vaughan-Mart. et al.) Kurtzman \& Suzuki (Aguirre-Güitrón et al. 2019), and Cryptococcus laurentii (Kuff.) C. E. Skinner (Bautista-Rosales et al. 2014) for the control of this disease. The postharvest phase is considered a suitable environment for the successful application of biological control agents; however, their success depends on their compatibility with other practices to achieve integrated management, among other factors (Di Francesco et al. 2016). Several studies previously conducted (Leverentz et al. 2000; Zhao et al. 2010; Liu et al. 2010; Wei et al. 2016) have integrated thermal treatment and biological control to increase the efficacy of controlling the disease.

Taking the previous reports on anthracnose into consideration, the objective of this study was to evaluate the efficacy of hydrothermal treatment and the antagonistic action of Pichia guilliermondii Wick., Candida oleophila Montrocher, and C. quercitrusa S. A. Mey. \& Phaff strains in assays in vitro and in vivo for anthracnose control in 'Ataulfo' mango.

\section{Materials And Methods}

\section{Antagonists and pathogen}

We used strains 71 (Genbank JX455762), 89 (Genbank JX993808), MN (Genbank JX993815), MNH (Genbank JX455757), and MZC (Genbank JX993807) of P. gui- 
lliermondii, strain 9 of C. oleophila (Genbank KX981191), and strain 42 of C. quercitrusa (Genbank KX98119), all isolated from huitlacoche galls in a previous study where it was observed that they were able to inhibit the growth of Ustilago maydis (DC.) Corda (Guevara-Vázquez et al. 2009). We also used two commercial $P$. guilliermondii reference strains: strain CDBB-932 (Wickerham 1966), which was obtained from the National Collection of Microbial Strains and Cell Cultures of CINVESTAV-IPN, and strain C-04568 (Laitila et al. 2007) obtained from the VTT Culture Collection of the Technical Research Centre of Finland. Strains preserved in potato dextrose agar (PDA) and mineral oil were reactivated in Petri dishes with YM medium ( $1 \mathrm{~L}$ of distilled water containing $10 \mathrm{~g}$ of glucose, $3 \mathrm{~g}$ of yeast extract, $3 \mathrm{~g}$ of malt extract, $5 \mathrm{~g}$ of peptone, and $20 \mathrm{~g}$ of agar). The pathogen Colletotrichum spp. was isolated from 'Ataulfo' mango fruits with typical anthracnose symptoms and cultured in Petri dishes with PDA medium (Wu et al. 2020; Weir et al. 2012). The fungus was incubated for six days in darkness at $25 \pm 1{ }^{\circ} \mathrm{C}$. The pathogen was identified by its distinctive morphological structures and purified with the hypha-tip technique.

\section{Hydrothermal treatment and antagonistic yeasts for the control of Colletotrichum spp.}

The effect of HT $\left(46.1{ }^{\circ} \mathrm{C}\right.$ for $\left.70 \mathrm{~min}\right)$ and yeasts P. guilliermondii, C. oleophila, and C. quercitrusa on Colletotrichum spp. were evaluated in in vitro and in vivo assays. The in vitro assays were performed in three study conditions to define the in vivo assays experimental design.

\section{In vitro assay}

The yeast strains were inoculated in Erlenmeyer flasks with $250 \mathrm{~mL}$ of NYDB liquid culture. These were kept in a rotary incubator (Lab Companion SI-300, Illinois, USA) at $150 \mathrm{rpm}$ for $72 \mathrm{~h}$ at $25^{\circ} \mathrm{C}$. The medium was then centrifuged (Mikro 220 Hettich Zentrifugen, Tuttlingen, Germany) at 1,735.1 $\mathrm{g}$ for $10 \mathrm{~min}$, and the pellet formed was washed with sterile distilled water. A cell suspension in distilled water was done with the help of a stirrer (Mixer VM-300, Gemmy Industrial Corporation, Taipei, Taiwan), and a solution with
$10^{8}$ cells $\bullet \mathrm{mL}^{-1}$ (Liu et al. 2010) was prepared with the aid of a Neubauer chamber (Marienfield, Laboratory Glassware, Kônigshofen, Germany). The Colletotrichum spp. conidia with six days of growth were removed from the culture surface with sterile distilled water and a magnetic stirrer. The suspension was homogenized and adjusted to $10^{5}$ conidia $\bullet \mathrm{mL}^{-1}$ (Kefialew and Ayalew 2008; Liu et al. 2010). The HT was applied in half the volume obtained from each prepared solution (Colletotrichum spp., P. guilliermondii, C. oleophila, and $C$. quercitrusa) in bain-marie equipment with temperature control.

The effect of HT and the antagonistic yeasts of $P$. guilliermondii, C. oleophila, and C. quercitrusa on Colletotrichum spp. were evaluated under three conditions:

$\mathrm{C}_{\text {noHT }} \mathrm{Y}_{\text {noHT }}$ : Effect of yeast on the growth area of Colletotrichum spp. For this purpose, a filter paper disc containing Colletotrichum spp. (C) and another disc with yeast $(\mathrm{Y})$ were placed in Petri dishes, both without HT. In this test, the most effective strains in the control of the fungus were determined.

$\mathrm{C}_{\mathrm{HT}} \mathrm{Y}_{\text {noHT }}$ : Effect of yeast on the growth area of Colletotrichum spp. previously subjected to HT. A disc with Colletotrichum spp. subjected to HT, and another disc with yeast without HT were placed in Petri dishes.

$\mathrm{C}_{\mathrm{HT}} \mathrm{Y}_{\mathrm{HT}}$ : Effect of yeast on the growth area of Colletotrichum spp. both previously subjected to HT. A disc with Colletotrichum spp. and another with yeast, both subjected to HT were placed in dishes.

In this latter condition, we observed the resistance of each of the strains to temperature, an important factor in antagonists biocontrol efficacy. High temperatures affect the viability of yeasts in biological control, in both pre or postharvest applications; therefore, it is essential to know the tolerance and response of yeasts to thermal stress for a successful application and biocontrol efficacy (Sui and Liu 2014).

The discs used were made of Whatman no. 1 sterile filter paper ( $5 \mathrm{~mm}$ in diameter). They were immersed in the antagonist solutions (with or without HT) and the pathogen (with or without HT) and were placed at two reference points, keeping the same distance in all dishes. The nine antagonistic strains (treatments) and one control treatment (Colletotrichum spp. disc without HT) were analyzed in each phase with three replicates at $25{ }^{\circ} \mathrm{C}$. The results of the experiment concluded when the fungus invaded the Petri dishes in the control. 
The pathogen and the antagonist growth areas were measured through photographs with ImageJ Image Analysis Software (Image Processing and Analysis in Java, version 1.52, National Institute of Health, USA). Pictures were taken with a dark background to contrast with the light color of the growth areas.

\section{In vivo assay}

A hydrothermal treatment of $46.1{ }^{\circ} \mathrm{C}$ for $70 \mathrm{~min}$ and the antagonism of $P$. guilliermondii, $C$. oleophila, and $C$. quercitrusa were evaluated, alone and combined, for the control of anthracnose in 'Ataulfo' mango fruits artificially inoculated with the pathogen. Strains CDBB-932 and MZC of P. guilliermondii, strain 9 of $C$. oleophila, and strain 42 of C. quercitrusa were selected due to the greater efficacy in the control of Colletotrichum spp. in vitro. The yeast and pathogen suspensions were prepared with a concentration of $10^{8}$ cells $\bullet \mathrm{mL}^{-1}$ (Zhao et al. 2010) and $10^{5}$ conidia $\bullet \mathrm{mL}^{-1}$ (Liu et al. 2010), respectively, as described in the in vitro assays.

The mango was collected in orchards established in Nueva Italia, Michoacán, México. The fruits were selected by size, uniform color, and absence of visual defects. Mangoes were disinfested by immersion in 2.5 $\%$ sodium hypochlorite solution for $3 \mathrm{~min}$, followed by a rinse with potable water (Vilaplana et al. 2020). Fruits were inoculated by immersion in the pathogen solution for $3 \mathrm{~min}$ and incubated for $24 \mathrm{~h}$ in plastic boxes. Subsequently, the fruits infected with the fungus were treated with yeast immersion for $3 \mathrm{~min}$ (T1-T5), HT (T6), or a combination of both (T7-T11). Therefore, the following treatments were formed: T1) C. oleophila 9, T2) C. quercitrusa 42, T3) Pichia CDBB-932, T4) Pichia MZC, T5) Yeast mixture $(9+42+$ CDBB-932 + MZC), T6) HT, T7) HT + C. oleophila 9, T8) HT + C. quercitrusa 42, T9) HT + Pichia CDBB-932, T10) HT + Pichia MZC, T11) HT + yeast mixture $(9+42+$ CDBB-932 + MZC). One treatment (T12) was used as a negative control (without HT and untreated).

Each treatment was applied to five fruits with three replicates. Fruits were stored for up to 20 days at room temperature $\left(20 \pm 2{ }^{\circ} \mathrm{C}\right)$ in plastic boxes kept at $95 \%$ relative humidity. Anthracnose severity (AS) was evaluated as percentage reduction of the damaged area by the fungus, determined as the difference between the damaged area in the negative control $(\mathrm{N})$ and the damaged area in treatments (T) (Oliveira et al. 2018) using the formula: AS $(\%)=[(\mathrm{N}-\mathrm{T}) / \mathrm{N}] * 100$.

\section{Statistical analysis}

Data were subjected to analysis of variance (ANOVA) with SAS version 9.1 statistical software (SAS 2004), using a completely randomized design (CRD) with the statistical model Yij $=\mu+\mathrm{Ti}+\bullet \mathbf{i j}$. Yeast growth area data were transformed with the logarithmic function, and the percentage (\%) severity was subjected to the Box-Cox transformation with $\lambda=0.01$. Transformations were made to satisfy the conditions of normality and homogeneity of variance. Comparison of means was performed with the Tukey test $(P \leq 0.05)$, and an adjustment of $\alpha$ was made with the Bonferroni test for protection against type I error.

\section{Results And Discussion}

\section{In vitro assay: Efficacy of hydrothermal treatment and antagonistic yeasts}

In the condition $\mathrm{C}_{\mathrm{noHT}} \mathrm{Y}_{\mathrm{noHT}}$, the results showed that strains CDBB-932, 9, 42, MZC, C-04568 and MN had greatest efficacy $(P=0.05)$ in the control of the pathogen $(10-18.6 \%)$ (Table 1$)$. These results are satisfactory and differ from what was reported in another study, where $P$. guilliermondii $\left(10^{8}\right.$ cells $\left.\bullet \mathrm{mL}^{-1}\right)$ could not control Colletotrichum acutatum J. H. Simmonds 1965 (Liu et al. 2010). Of the strains mentioned above, C-04568 has been reported to suppress the growth of several species of Fusarium (Laitila et al. 2007). On the other hand, the yeast growth area of strain 42 of $C$. quercitrusa was the highest growth when it interacted with Colletotrichum spp. By contrast, strain CDBB-932 of P. guilliermondii, which showed the greatest antagonistic effect on the fungus, had the lowest growth (Table 1).

Antagonistic microorganisms have several modes of action for pathogen control. Some of them are competition for space and nutrients, production of lytic enzymes, parasitism, oxidative stress, and induced resistance (Di Francesco et al. 2016). Figure 1 shows that, apparently, the most effective $P$. guilliermondii yeasts used different mechanisms for the control of Colletotrichum spp. strain CDBB-932 of $P$. guilliermondii 
Table 1. Effect of strains of Pichia guilliermondii, Candida oleophila, and Candida quercitrusa yeasts on mycelial growth of Colletotrichum spp. in vitro after 13-day storage at $25^{\circ} \mathrm{C}$.

\begin{tabular}{lcc}
\hline \multicolumn{1}{c}{ Strain } & $\begin{array}{c}\text { mycelial growth } \\
\left(\mathrm{mm}^{2}\right)\end{array}$ & $\begin{array}{c}\text { yeast growth } \\
\left(\mathrm{mm}^{2}\right)\end{array}$ \\
\hline Control & $5104.7 \pm 171.9 \mathrm{a}$ & - \\
Pichia guilliermondii & & \\
MNH & $4918.4 \pm 99.0 \mathrm{ab}$ & $138.71 \pm 8.4 \mathrm{ab}$ \\
89 & $4716.7 \pm 141.3 \mathrm{a}-\mathrm{c}$ & $140.36 \pm 34.8 \mathrm{ab}$ \\
71 & $4669.0 \pm 143.1 \mathrm{a}-\mathrm{c}$ & $162.19 \pm 15.4 \mathrm{ab}$ \\
MN & $4593.8 \pm 94.6 \mathrm{~b}-\mathrm{d}$ & $155.37 \pm 12.9 \mathrm{ab}$ \\
C-04568 & $4508.4 \pm 83.5 \mathrm{~b}-\mathrm{d}$ & $142.23 \pm 16.2 \mathrm{ab}$ \\
MZC & $4411.2 \pm 86.8 \mathrm{~cd}$ & $145.28 \pm 6.6 \mathrm{ab}$ \\
CDBB-932 & $4154.3 \pm 49.3 \mathrm{~d}$ & $106.10 \pm 0.4 \mathrm{~b}$ \\
Candida oleophila & & $145.91 \pm 23.9 \mathrm{ab}$ \\
9 & $4180.0 \pm 100.2 \mathrm{~d}$ & \\
Candida quercitrusa & & $203.07 \pm 21.7 \mathrm{a}$ \\
42 & $4276.5 \pm 20.7 \mathrm{~d}$ & \\
\hline
\end{tabular}

Data correspond to the mean value \pm standard deviation. a,b,c,d Different superscripts in the same column indicate that the means differ significantly $(P \leq 0.05)$.

presented a small inhibition halo of approximately 0.5 $\mathrm{cm}$, being the only one that showed such behavior. This inhibition halo was light in color, but due to dark background photography, dark tones are observed. This mode of action can be attributed to the secretion of some yeast inhibitory substances, if it is considered that yeasts can produce exogenous chemicals that cause adverse effects on some pathogens (Guo et al. 2015). Similar behavior was reported in a study that evaluated Brevundimonas diminuta (Leifson and Hugh 1954) Segers et al. 1994, Stenotrophomonas maltophilia (Hugh 1981) Palleroni and Bradbury 1993, a member of Enterobacteriaceae, Candida membranifaciens (Lodder \& Kreger) Wick. \& K. A. Burton, 1954, and the yeast isolated to control C. gloeosporioides (Penz.) Penz. \& Sacc., 1884 (Kefialew and Ayalew 2008). The results of this study showed that filtrated antagonist cultures had a more significant antagonistic effect than cell suspensions; the authors attributed this result to the possible presence of inhibitory substances.

Regarding strains 9 (C. oleophila), MZC, and C-04568 (P. guilliermondii), the pathogen maintained its growth when it joined the colonies margin of these yeasts. A similar response was found when $P$. guilliermondii Moh 10 was evaluated for the control of Botryodiplodia theobromae (Pat.) Griffon \& Maubl.,
1909 (Mohamed and Saad 2009). Finally, strains 42 (C. quercitrusa) and MN (P. guilliermondii) were slightly invaded by the fungus. Still, they also had the most significant growth, so the mode of action could be competition for space.
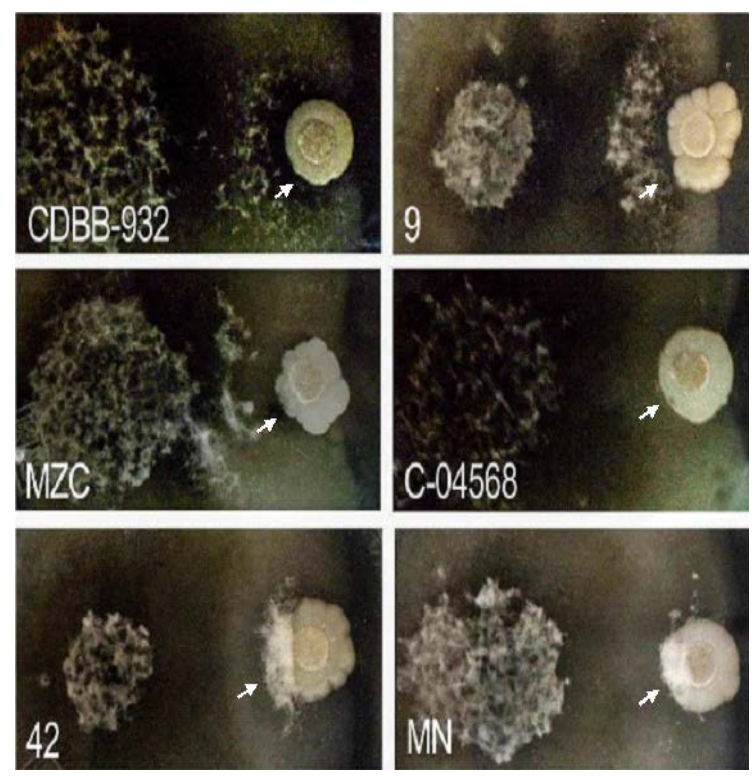

Figure 1. In vitro interaction of Colletotrichum spp. and the most effective antagonistic yeasts (pointed by the arrow) in pathogen control after 13-day storage. Inhibition halo: CDBB-932 (Pichia guilliermondii). Inhibition at the margin: 9 (Candida oleophila), MZC, and C-04568 (Pichia guilliermondii). No inhibition: 42 (Candida quercitrusa) and MN (Pichia guilliermondii). 
When evaluating the combination of HT and antagonistic yeasts $\left(\mathrm{C}_{\mathrm{HT}} \mathrm{Y}_{\text {no-HT }}\right.$ and $\left.\mathrm{C}_{\mathrm{HT}} \mathrm{Y}_{\mathrm{HT}}\right)$ on the fungal mycelial growth, it was observed that the postharvest pathogen was inhibited. This behavior is consistent with that reported in a study on the use of heat treatment to control Botrytis cinerea Persoon, 1794 (Di Francesco et al. 2018) and Fusarium spp. (Petreš et al. 2020). In the present study, HT inhibited fungal growth; however, a limitation of heat treatment is that it has little effect when pathogen contamination occurs in the post-treatment storage period (Leverentz et al. 2000). Therefore, and based on the results of the first condition (both organisms without HT), it can be argued that the complementary use of yeasts may be a way to prevent the growth of Colletotrichum spp. in the event of post-HT contamination.

Results indicate that the yeasts resist high temperatures; however, there is a significant reduction $(P \leq 0.05)$ in the growth area when they are subjected to HT (Table 2). Yeasts showed greater growth in the $\mathrm{C}_{\mathrm{HT}} \mathrm{Y}_{\text {no-HT }}$ combination. This can be attributed to the fact that HT inhibited Colletotrichum spp. Consequently, the yeasts could develop without problems due to a lack of competition for space and nutrients. On the other hand, HT $\left(\mathrm{C}_{\mathrm{HT}} \mathrm{Y}_{\mathrm{HT}}\right)$ significantly damaged $C$. oleophila (strain 9) and C. quercitrusa (strain 42) since they did not develop growth, whereas the evaluated $P$. guilliermondii strains were not affected to such an extent; apparently, the latter were thermotolerant. This contrasts with another study where it was reported that heat treatment at $38^{\circ} \mathrm{C}$ for $24 \mathrm{~h}$ had a harmful effect on P. guilliermondii (Zhao et al. 2010).

The evaluation of the growth of the nine strains together with Colletotrichum spp. $\left(\mathrm{C}_{\text {noHT }} \mathrm{Y}_{\text {noHT' }}\right.$ $\mathrm{C}_{\mathrm{HT}} \mathrm{Y}_{\text {noHT }}$ and $\mathrm{C}_{\mathrm{HT}} \mathrm{Y}_{\mathrm{HT}}$ ) was useful to define the most appropriate form of applying the treatments in the in vivo assays. Initially, the option of applying the yeasts together with HT in the fruits was considered. Still, because C. oleophila (strain 9) and C. quercitrusa (strain 42) did not resist heat, it was decided first to apply the HT and then the yeasts.

Although statistically strains CDBB-932, 9, 42, MZC, C-04568, and MN had the same control ability against the pathogen (Table 1), only the first four were selected for in vivo evaluation.

\section{In vivo assay: Efficacy of hydrothermal treatment and antagonistic yeasts}

Fruits treated only with yeasts had the highest degree of severity (37.4 to $71 \%$ ) and were not statistically different from each other (Table 3). This is consistent with the results in vitro assay, where there was also no statistically significant difference among them; however, the order of the most effective strains did not coincide. De Capdeville et al. (2007) evaluated antagonistic microorganisms for the control of anthracnose on papaya fruits. They found that the most effective strains in in vitro and in vivo assays were not the same, similar to the present research. This behavior may be due to the fact that the culture medium conditions are not the same as those found in the fruits and, therefore, each strain shows different capacities. The yeast mixture (9 $+42+$ CDBB-932 + MZC) had no effect on the control of anthracnose; the effect of P. guilliermondii strain MZC was more significant than that produced by the mixture with $37.4 \%$.

An inhibitory effect of anthracnose on mangoes treated with the MZC strain was observed (Figure 2B) with respect to control (Figure 2A), although statistically, the effect was the same. In the mangoes treated only with HT, and in those where HT was combined with antagonistic yeasts, we observed a better control

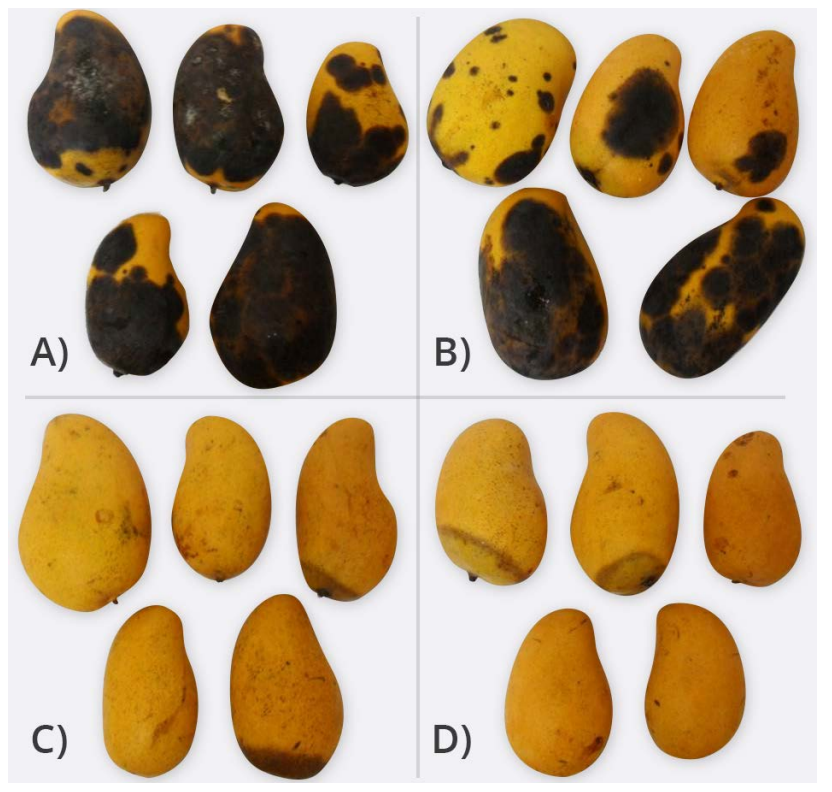

Figure 2. Anthracnose severity after 20-day storage at room temperature $(20 \pm 2$ ${ }^{\circ} \mathrm{C}$ ) in 'Ataulfo' mango inoculated with Colletotrichum spp.: A) Control (56.2 \%), B) Pichia guilliermondii MZC (37.3\%), C) HT (3.2\%), D) HT + Candida quercitrusa 42 (1.8\%). HT: Hydrothermal treatment $\left(46.1^{\circ} \mathrm{C}\right.$ for $\left.70 \mathrm{~min}\right)$. 
Table 2. Growth area of nine Pichia guilliermondii strains in interaction with Colletotrichum spp. for 13 days storage at $25^{\circ} \mathrm{C}$ evaluated under three in vitro conditions.

\begin{tabular}{|c|c|}
\hline Condition & $\begin{array}{c}\text { Yeast growth } \\
\left(\mathrm{mm}^{2}\right)\end{array}$ \\
\hline $\mathrm{C}_{\mathrm{HT}} \mathrm{Y}_{\text {non-HT }}$ & $181.50 \pm 37.5 \mathrm{a}$ \\
\hline $\mathrm{C}_{\text {no-HT }} Y_{\text {non-HT }}$ & $147.95 \pm 28.1 b$ \\
\hline $\mathrm{C}_{\mathrm{HT}} \mathrm{Y}_{\mathrm{HT}}$ & $112.66 \pm 61.5 c$ \\
\hline
\end{tabular}

HT: $46.1^{\circ} \mathrm{C}$ for 70 min. $\mathrm{C}_{\mathrm{HT}} \mathrm{Y}_{\text {non-HT: }}$ : Colletotrichum spp. with HT and yeast without HT. $\mathrm{C}_{\text {non-HT}} \mathrm{Y}_{\text {non-H }}$ : Colletotrichum spp. without HT and yeast without HT. $\mathrm{C}_{\mathrm{HT}} \mathrm{Y}_{\mathrm{HT}}$ : Colletotrichum spp. with HT and yeast with HT. Data correspond to the mean value \pm standard deviation. ${ }^{a, b, c}$ Different superscripts in the same column indicate that the means differ significantly $(P \leq 0.05)$.

Table 3. Effect of hydrothermal treatment (HT), antagonist yeasts of Pichia guilliermondii (MZC and CDBB-932), Candida oleophila (strain 9), and Candida quercitrusa (strain 42) or a combination of both on anthracnose severity in mango fruits after 20-day storage at room temperature $\left(20 \pm 2{ }^{\circ} \mathrm{C}\right)$.

\begin{tabular}{lcc}
\hline \multicolumn{1}{c}{ Treatment } & Severity $(\%)$ & Efficacy $(\%)$ \\
\hline $\mathrm{T}_{1}: 9$ & $70.94 \pm 13.5 \mathrm{a}$ & - \\
$\mathrm{T}_{3}:$ CDBB-932 & $63.95 \pm 12.2 \mathrm{a}$ & - \\
$\mathrm{T}_{12}:$ Control & $56.24 \pm 10.9 \mathrm{a}$ & 0.0 \\
$\mathrm{~T}_{5}:$ Yeast mixture & $55.89 \pm 21.9 \mathrm{a}$ & 0.6 \\
$\mathrm{~T}_{2}: 42$ & $55.76 \pm 21.3 \mathrm{a}$ & 0.9 \\
$\mathrm{~T}_{4}: \mathrm{MZC}$ & $37.35 \pm 30.0 \mathrm{a}$ & 33.6 \\
$\mathrm{~T}_{11}: \mathrm{HT}+$ Yeast mixture & $3.60 \pm 1.6 \mathrm{~b}$ & 93.6 \\
$\mathrm{~T}_{7}: \mathrm{HT}+9$ & $3.55 \pm 1.5 \mathrm{~b}$ & 93.7 \\
$\mathrm{~T}_{6}: \mathrm{HT}$ & $3.27 \pm 1.5 \mathrm{~b}$ & 94.2 \\
$\mathrm{~T}_{10}: \mathrm{HT}+$ MZC & $3.10 \pm 0.8 \mathrm{~b}$ & 94.5 \\
$\mathrm{~T}_{9}: \mathrm{HT}+$ CDBB-932 & $2.59 \pm 2.0 \mathrm{~b}$ & 95.4 \\
$\mathrm{~T}_{8}: \mathrm{HT}+42$ & $1.79 \pm 0.6 \mathrm{~b}$ & 96.8 \\
\hline
\end{tabular}

HT: $46.1^{\circ} \mathrm{C}$ for $70 \mathrm{~min}$. Yeast mixture: $9+42+\mathrm{CDBB}-932+\mathrm{MZC}$. Data correspond to the mean value \pm standard deviation. a,b Different superscripts in the same column indicate that the means differ significantly $(P \leq 0.05)$.

of anthracnose (Figure 2C, 2D). We did not observe significant differences between them $(P \leq 0.05)$, but we did with the control and individual application of yeasts. According to the results, the most effective treatment was HT + C. oleophila 42 with $96.8 \%$ efficacy in the anthracnose control, although a similar effect was observed with hydrothermal treatment only.

Yeasts were not as effective in controlling Colletotrichum spp. compared to the effect of P. guilliermondii on other pathogens such as B. theobromae in guava (Mohamed and Saad 2009) and Colletotrichum capsici (Schwein.) Andrus \& W. D. Moore, 1935 (Chanchaichaovivat et al. 2007); C. oleophilla on Colletotrichum musae (Berk. \& M. A. Curtis) Arx, 1957 in banana (Bastiaanse et al. 2010); and C. quercitrusa on C. capsici in chilli (Chanchaichaovivat et al. 2007). On the other hand, the effect of HT was greater than that of the yeasts for controlling the fungus, thereby agreeing with another study conducted in mangoes from different ecologies of Ethiopia (Kefialew and Ayalew 2008). The result of this work was significant since the anthracnose could be controlled with HT, considering that there are reports where this same method also controls the fruit fly in 'Ataulfo' mango (Luna et al. 2006). It has been pointed out that, in postharvest systems, an acceptable level of harm is less than $5 \%$ (Janisiewicz and Korsten 2002). Therefore, the combination of HT with the antagonistic yeasts 
proved to be very effective because it resulted in damages of only $1.9 \%$ after 20 -day storage at $20{ }^{\circ} \mathrm{C}$. Heat treatment can help eradicate fungal spores at the time of application, but they only have a slight effect in protecting the fruit from future infections. By contrast, antagonists do have this property, so the use of yeasts could complement preventative control in postharvest mango storage (Sui et al. 2016).

\section{Conclusions}

In the in vitro assay, $\mathrm{HT}\left(46.1^{\circ} \mathrm{C}\right.$ for $\left.70 \mathrm{~min}\right)$ completely inhibited Colletotrichum spp. Regarding the yeasts, strains 9 (C. oleophila), 42 (C. quercitrusa), MZC, MN, CDBB-932, and C-04568 (P. guilliermondii) were the most effective in controlling (between 10 and $18.6 \%$ ) mycelial growth of the pathogen. In the in vivo assay, the combination of HT and C. quercitrusa (strain 42) controlled anthracnose in 'Ataulfo' mango with an efficacy of $96.8 \%$ for 20 days. The hydrothermal treatment combined with yeasts could be implemented for the preventative control of the anthracnose in 'Ataulfo' mango.

\section{Acknowledgments}

The authors would like to thank the Autonomous Chapingo University (projects 105401001 and 115401001) and CONACYT (project 47725) for funding this research, the National Collection of Microbial Strains and Cell Cultures of CINVESTAV and VTT Culture Collection of Finland for providing strains CDBB-932 and C-04568, respectively, and Ma. Carmen Ybarra Moncada for her critical reading of the manuscript and statistical suggestions.

\section{Conflict Of Interest}

There is no conflict of interest in the present investigation. 


\section{Literature Cited}

Andrade JL, De la Barrera E, Reyes-García C, Ricalde MF, Vargas-Soto G, Cervera JC. 2007. El metabolismo ácido de las crasuláceas: diversidad, fisiología ambiental y productividad. Boletín de la Sociedad Botánica de México 81: 37-50. http://doi.org/10.17129/botsci.1764

Armella MA, Yanez-López L, Soriano J, Ramírez R. 2003. Phenology, postharvest physiology and marketing of pitaya (Stenocereus griseus, L.) as a sustainable resourse. Acta Horticulturae 598: 251-254. http://doi. org/10.17660/ActaHortic.2003.598.37

Benzie IFF, Strain JJ. 1996. The ferric reducing ability of plasma (FRAP) as a measure of "antioxidant power": The FRAP assay. Analytical Biochemistry 239: 70-76. http://doi.org/10.1006/abio.1996.0292

Casas A, Otero-Arnaiz A, Pérez-Negrón E, ValienteBanuet A. 2007. In situ management and domestication of plants in Mesoamerica. Annals of Botany 100: 1101-1115. http://doi.org/10.1093/aob/mcm126

Castellanos-Santiago E, Yahia EM. 2008. Identification and quantification of betalains from the fruits of 10 Mexican prickly pear cultivars by high-performance liquid chromatography and electrospray ionization mass spectrometry. Journal of Agricultural and Food Chemistry 56: 5758-5764. http://doi.org/10.1021/ jf800362t

Chuck-Hernández C, Parra-Saldívar R, Sandate-Flores L. 2015. Pitaya (Stenocereus spp.). In: Caballero B, Finglas PM, Toldrá F, editors. Encyclopedia of Food and Health. Oxford, Elsevier. P. 385-391.

Correa-Betanzo J, Jacob JK, Perez-Perez C, Paliyath G. 2011. Effect of a sodium caseinate edible coating on berry cactus fruit (Myrtillocactus geometrizans) phytochemicals. Food Research International 44: 1897-1904. http://doi.org/10.1016/J.FOODRES.2010.10.053

García-Cruz L, Valle-Guadarrama S, Salinas-Moreno Y, Joaquín-Cruz E. 2013. Physical, chemical, and antioxidant activity characterization of pitaya (Stenocereus pruinosus) fruits. Plant Foods for Human Nutrition 68: 403-410. http://doi.org/10.1007/s11130-013-0391-8

García-Cruz L, Valle-Guadarrama S, Salinas-Moreno Y, Luna-Morales CdelC. 2016. Postharvest quality, soluble phenols, betalains content, and antioxidant activity of Stenocereus pruinosus and Stenocereus stellatus fruit. Postharvest Biology and Technology 111: 69-76. http:// doi.org/10.1016/j.postharvbio.2015.07.004
García-Cruz L, Dueñas M, Santos-Buelgas C, ValleGuadarrama S, Salinas-Moreno Y. 2017. Betalains and phenolic compounds profiling and antioxidant capacity of pitaya (Stenocereus spp.) fruit from two species (S. pruinosus and S. stellatus). Food Chemistry 234: 111-118. http://doi.org/10.1016/j.foodchem.2017.04.174

Hübert T, Lang C. 2012. Artificial fruit: Postharvest online monitoring of agricultural food by measuring humidity and temperature. International Journal of Thermophysics 33: 1606-1615. http://doi.org/10.1007/ s10765-011-1101-0

Liu R, Gao H, Chen H, Fang X, Wu W. 2019. Synergistic effect of 1-methylcyclopropene and carvacrol on preservation of red pitaya (Hylocereus polyrhizus). Food Chemistry 283: 588-595. http://doi.org/10.1016/J. FOODCHEM.2019.01.066

López-Palestina CU, Aguirre-Mancilla CL, Raya-Pérez JC, Ramírez-Pimentel JG, Gutiérrez-Tlahque J, HernándezFuentes AD. 2018. The effect of an edible coating with tomato oily extract on the physicochemical and antioxidant properties of garambullo (Myrtillocactus geometrizans) fruits. Agronomy 8: 248. http://doi.org/10.3390/ agronomy 8110248

Martínez-Mendoza AA, Franco-Mora O, Sánchez-Pale JR, Rodríguez-Núñez JR, Castañeda-Vildózola Á. 2020. Evaluación de recubrimientos comestibles a base de pectina de tejocote (Crataegus mexicana Moł. \& Sess, ex DC., Rosaceae) en la poscosecha de tihuixocote (Ximenia americana L., Olacaceae). Acta Agrícola y Pecuaria 6: E0061004. https://doi.org/10.30973/aap/2020.6.0061004

Ortega-Hernández E, Welti-Chanes J, Jacobo-Velázquez DA. 2018. Effects of UVB light, wounding stress, and storage time on the accumulation of betalains, phenolic compounds, and ascorbic acid in red prickly pear (Opuntia ficus-indica cv. Rojo Vigor). Food and Bioprocess Technology 11: 2265-2274. https://doi. org/10.1007/s11947-018-2183-5

Parra F, Blancas JJ, Casas A. 2012. Landscape management and domestication of Stenocereus pruinosus (Cactaceae) in the Tehuacán Valley: Human guided selection and gene flow. Journal of Ethnobiology and Ethnomedicine 8: 32. https://doi.org/10.1186/1746-4269-8-32

Re R, Pellegrini N, Proteggente A, Pannala A, Yang M, RiceEvans C. 1999. Antioxidant activity applying an improved ABTS radical cation decolorization assay. Free Radical Biology and Medicine 26: 1231-1237. https://doi. org/10.1016/S0891-5849(98)00315-3 
Rives-Castillo SCH, Ventura-Aguilar RI, Hernández-López M, Bautista-Baños S. 2018. Evaluación de recubrimientos biodegradables para la conservación en fresco de jitomate Kenton. Acta Agrícola y Pecuaria 4: 80-91. https://doi.org/10.30973/aap/2018.4.3/2

Rodríguez-Sánchez JA, Cruz y Victoria MT, BarragánHuerta BE. 2017. Betaxanthins and antioxidant capacity in Stenocereus pruinosus: Stability and use in food. Food Research International 91: 63-71. https://doi. org/10.1016/j.foodres.2016.11.023

Rosas-Benítez A, Trujillo-Cárdenas L, Valle-Guadarrama S, Salinas-Moreno Y, García-Cruz L. 2016. Quality attributes of pitaya (Stenocereus pruinosus) fruit handled in postharvest with and without thorns under refrigerated storage. Revista Chapingo Serie Horticultura 22: 191207. https://doi.org/10.5154/r.rchsh.2016.04.011

Sant'Anna V, Gurak PD, Marczak LDF, Tessaro IC. 2013. Tracking bioactive compounds with colour changes in foods - A review. Dyes and Pigments 98: 601-608. https://doi.org/10.1016/J.DYEPIG.2013.04.011

Shirai K, Hernandez CG, Mejía P, Blanco S, RománGuerrero A, Yañez L, Escalona-Buendía HB. 2016. Postharvest preservation of cactus fruits produced in semidesertic area of Oaxaca by biopolymer coatings. The International Journal of Interdisciplinary Social Sciences: Annual Review 11: 15-26. http://doi. org/10.18848/1833-1882/CGP/15-26

Singleton VL, Rossi JA. 1965. Colorimetry of total phenolics with phosphomolybdic-phosphotungstic acid reagents. American Journal of Enology and Viticulture 16: $144-158$

Tomás-Barberan FA, Ferreres F, Gil MI. 2000. Antioxidant phenolic metabolites from fruit and vegetables and changes during postharvest storage and processing. Studies in Natural Products Chemistry 23: 739-795. https://doi.org/10.1016/S1572-5995(00)80141-6

Torres R, Montes EJ, Pérez OA, Andrade RD. 2013. Relación del color y del estado de madurez con las propiedades fisicoquímicas de frutas tropicales. Informacion Tecnológica 24: 51-56. https://doi.org/10.4067/ S0718-07642013000300007

Torres-León C, Vicente AA, Flores-López ML, Rojas R, Serna-Cock L, Alvarez-Pérez OB, Aguilar CN. 2018. Edible films and coatings based on mango (var. Ataulfo) by-products to improve gas transfer rate of peach. LWT - Food Science \& Technology 97: 624-631. https://doi. org/10.1016/j.lwt.2018.07.057
Valero D, Serrano M. 2010. Postharvest Biology and Technology for Preserving Fruit Quality. Taylor \& Francis. Florida, USA.

Valle-Ortiz DJ, Gómez-Cruz A, Hernández-Fuentes AD, Valle-Guadarrama S. 2019. Microbial control in white cactus pear with biopolymeric coating of chitosan, candelilla wax and thyme essential oil. Revista Fitotecnia Mexicana 42: 201-207. https://doi.org/10.35196/ rfm.2019.3.201-207

Vargas-Campos L, Valle-Guadarrama S, Martínez-Bustos F, Salinas-Moreno Y, Lobato-Calleros C, Calvo-López AD. 2018. Encapsulation and pigmenting potential of betalains of pitaya (Stenocereus pruinosus) fruit. Journal of Food Science and Technology 55: 2436-2445. https:// doi.org/10.1007/s13197-018-3161-7

Wu Y, Xu J, He Y, Shi M, Han X, Li W, Zhang X, Wen X. 2019. Metabolic profiling of pitaya (Hylocereus polyrhizus) during fruit development and maturation. Molecules 24: 1114. https://doi.org/10.3390/molecules24061114

Zahid N, Ali A, Siddiqui Y, Maqbool M. 2013. Efficacy of ethanolic extract of propolis in maintaining postharvest quality of dragon fruit during storage. Postharvest Biology and Technology 79: 69-72. https://doi. org/10.1016/j.postharvbio.2013.01.003 